\title{
O assédio moral nas relações de trabalho do profissional de secretariado executivo
}

\section{The executive secretarial professional moral harassment in the workplace}

\section{Letícia Saboia de Castro ${ }^{1}$ \\ Thays Lyanny da Cunha Garcia da Rocha ${ }^{2}$}

Resumo: O assédio moral é um tema alarmante e que é debatido com frequência na sociedade. A temática desta pesquisa justifica-se, primeiramente, por sua relevância e dado o fato de o assédio moral se tratar de um crime que pode gerar consequências sérias e irreversíveis para a vítima e, em seguida, pelo desejo de expor essa temática no real cotidiano do secretário executivo. Assim, a questão que a pesquisa propõe é: Como está o cenário da prática de assédio moral junto ao profissional de Secretariado Executivo? Com isso, tem-se por objetivo geral analisar o cenário do possível assédio moral na profissão de Secretariado Executivo. A metodologia adotada para a realização da pesquisa foi a descritiva de abordagem qualitativa e quantitativa, em uma pesquisa de campo em três fases. Na primeira fase foi realizada entrevista com uma profissional de Secretariado Executivo vítima de assédio moral; na segunda fase, com uma representante do Sindicato das Secretárias e Secretários do Estado do Ceará; e, por fim, foram aplicados questionários junto a profissionais da área de Secretariado Executivo de todo o Brasil, por meio dos quais se obteve 137 retornos. Para a análise dos dados foi utilizada a metodologia de análise de conteúdo. Dessa forma, constatou-se que a prática do assédio moral ocorre com os profissionais de Secretariado Executivo participantes da pesquisa e que é comum o assediador ser o superior direto a esse profissional. Além disso, tem-se que as

\footnotetext{
${ }^{1}$ Graduada em Secretariado Executivo pela Universidade Federal do Ceará. E-mail: leticia@ fonteles.com.br

${ }^{2}$ Mestranda em Administração e Controladoria pela Universidade Federal do Ceará. Especialista em Sustentabilidade Empresarial e Responsabilidade Social pela UNICHRISTUS. Bacharela em Secretariado Executivo pela Universidade Federal do Ceará. E-mail: thayslyanny@ hotmail.com
} 
consequências dessa prática estão relacionadas principalmente ao estresse e outros problemas que impactam a vida pessoal, afetando a saúde.

Palavras-chave: Assédio Moral; Abuso de poder; Secretariado Executivo.

Abstract: Moral harassment is an alarming subject which is often discussed in society. The research theme is justified, firstly for its relevance and due to the fact that moral harassment is a crime that can have serious and irreversible consequences for the victim; and secondly for the aim to expose this theme in the executive secretarial profession daily reality. The question that this study proposes is: How is the scenario of the practice of moral harassment towards the executive secretarial professional? This paper general aim is to analyze the scenario of possible moral harassment towards the executive secretarial profession. A descriptive, qualitative and quantitative approach was carried out by means of a field research in three phases. In the first phase an interview was carried out with an executive secretary victim of moral harassment; in the second phase, with a representative of the Secretaries' Union in the State of Ceará; and finally, questionnaires were applied to executive secretarial professionals from all over Brazil and 137 returns were obtained. The methodology of content analysis was used for the data. The results revealed that the practice of moral harassment happens among the executive secretarial professionals of the research and that it is common for the harasser to be the immediate boss to this professional. Furthermore, this practice consequences are mainly related to stress and other problems that impact personal life affecting the victim's health as well.

Keywords: Moral Harassment; Abuse of power; Secretarial Science.

\section{Introdução}

O contexto social vigente reflete um cenário em que a violência se apresenta de variadas formas, inclusive nas relações de trabalho dentro das organizações. O assédio moral é um fenômeno global que é observado desde o surgimento da vida em sociedade; ocorre muito frequentemente, tanto no ambiente organizacional como fora dele. Muitas pessoas se submetem a 
essa situação e, na maioria das vezes, não conseguem identificar tal agressão ou têm medo de perder o emprego.

A maior exposição desse tema ocorreu no final do século $\mathrm{XX}$, em virtude de uma grande preocupação em relação aos direitos humanos essenciais, entre eles o da dignidade da pessoa humana, e também da busca da melhoria das condições de trabalho (Hirigoyen, 2008). Devido a fatores como a globalização, o avanço das tecnologias, a maior concorrência no mercado e a expansão da sociedade capitalista, as organizações tornaram-se mais competitivas, concentrando, assim, seu objetivo maior, na maximização dos lucros, muitas vezes deixando de lado as relações humanas.

A profissão de secretário executivo evoluiu, tornando-se este um profissional mais capacitado, com visão holística, capaz de agregar valor às instituições, possuindo nelas, então, um papel essencial, pois atua junto a todos os níveis organizacionais, exercendo maior poder de decisão e contribuindo para a obtenção dos resultados planejados (Paes et al., 2015).

A escolha da temática abordada no presente estudo justifica-se, primeiramente, por sua relevância e porque o assédio moral se trata de um crime que pode gerar consequências sérias e irreversíveis para a vítima e, em seguida, pelo desejo de expor o real cotidiano do ambiente organizacional, focalizando o secretário executivo, que, por ser um profissional que tem contato direto com todos os setores de uma organização e pelo fato de haver, ainda hoje, preconceitos e estereótipos relacionados a esta profissão, pode tornar-se um profissional mais vulnerável ao assédio moral. Com o intuito de fazer com que as pessoas, tanto os empresários quanto os colaboradores, reflitam sobre a dimensão do assunto é que se justifica esta pesquisa, para tornar possível, por meio de conscientização e empatia, a redução dos casos de assédio moral que assolam a maioria das relações de trabalho.

Dessa forma, a questão que a pesquisa propõe é: Como está o cenário da prática de assédio moral junto ao profissional de Secretariado Executivo? Para averiguá-la, tem-se por objetivo geral analisar o cenário do assédio moral na profissão de Secretariado Executivo e, como objetivo específico, pretende-se:

a) Identificar por quem é praticado o assédio moral contra o profissional de

\begin{tabular}{l|l|l|l|l|l} 
(C) Revista SCRIBES & Viçosa, $M G$ & v. 1 & n. 1 & Julho/2020 & ISSN 2675-4401 \\
\hline
\end{tabular}


Secretariado Executivo;

b) Verificar as consequências causadas pelo assédio moral, tanto na vida pessoal quanto na carreira profissional das vítimas;

c) Descrever quais medidas poderiam ser adotadas pelas empresas para o combate ao assédio moral na visão dos profissionais de Secretariado Executivo.

A pesquisa é caracterizada como descritiva de abordagem qualitativa e quantitativa. Também foi realizada uma pesquisa de campo em três fases: Na primeira, foi realizada uma entrevista com uma profissional de Secretariado Executivo vítima de assédio moral; na segunda, com uma representante do Sindicato das Secretárias e Secretários do Estado do Ceará; e, por fim, foram aplicados questionários junto a profissionais da área de Secretariado Executivo de todo o Brasil que participam de grupos de Facebook e WhatsApp, pelos quais foram obtidos 137 retornos com representatividade de pelo menos um estado de cada região do país. Para a etapa de análise dos dados coletados, foi utilizada a metodologia de análise de conteúdo.

Esta pesquisa está estruturada em quatro seções. A primeira possui conteúdo introdutório, problematização, justificativa, objetivo geral e objetivos específicos que serviram de base para este estudo. Na segunda seção, encontra-se o referencial bibliográfico que foi utilizado para fundamentação teórica do problema e para proporcionar embasamento para realização de análise e interpretação dos resultados obtidos. A terceira seção aborda os procedimentos metodológicos e instrumentos de coleta utilizados para obtenção dos resultados esperados, a quarta e última, consiste na conclusão, contextualizando teoria, objetivos e resultados obtidos ao longo deste estudo.

\section{Assédio moral nas organizações}

O assédio moral não é um fato novo, trata-se de um fenômeno que está presente nas relações sociais e, principalmente, nas relações de trabalho há bastante tempo. Entretanto, não é uma temática amplamente discutida nas organizações. Freitas (2002) afirma que o assédio moral no cotidiano do trabalho confunde-se com o próprio histórico do trabalho, mas somente no início 
dos anos de 1990 o assédio moral começou a ser tratado como um fenômeno destrutivo que reduz a produtividade e favorece o absenteísmo, dadas as consequências psicológicas que envolve. Nesse sentido, Alkimin (2008) afirma que não são apenas as más condições de trabalho e os fatores ambientais que afetam o bem-estar do colaborador, mas também as relações insidiosas com os demais membros da organização.

Com as mudanças no mercado de trabalho, influenciadas pela globalização, pelos avanços tecnológicos e pelas novas relações de trabalho, tornam-se mais frequentes os casos de assédio moral. Conforme Martiningo e Siqueira (2015), os efeitos do assédio moral externam-se para a sociedade em geral, tendo em vista que as pessoas têm múltiplos papéis: Funcionário, cliente, contribuinte e cidadão; "portanto, o assédio moral que ocorre no ambiente de trabalho pode ocasionar múltiplos custos para a sociedade como um todo" (Martiningo \& Siqueira, 2015, p. 16).

Conforme Einarsen et al. (2003), o assédio moral nas organizações é permeado por diversos fatores, como os culturais e socioeconômicos, e afeta vários públicos, de quem sofre o assédio a toda a organização, no geral. Assim, Hirigoyen (2008) destaca que pesquisas apontam que a violência nas relações de trabalho ocorre com mais facilidade em instituições nas quais os objetivos da gestão não são muito claros e as situações de estresse são constantes, ou seja, em ambientes em que não há o fortalecimento da cultura e dos valores organizacionais.

A seguir, é apresentada uma abordagem histórica acerca do contexto em que surgiu a prática do assédio moral a partir da visão de renomados autores que discutem essa temática.

\subsection{Classificações acerca do assédio moral}

Acerca das classificações, o assédio moral apresenta-se de várias formas nas organizações. Para que determinados atos se caracterizem como assédio moral, é necessário considerar alguns aspectos, como repetição sistemática, intencionalidade (por exemplo, forçar o outro a abrir mão do emprego), direcionalidade (em que as ações são específicas a um indivíduo do grupo), temporalidade (a frequência durante a jornada de trabalho) e degradação gerada a 
partir das condições de trabalho (Heloani, 2004).

Quanto à tipologia, existem várias classificações para o assédio moral. Hirigoyen (2008) propôs as classificações a seguir partindo da análise dos resultados obtidos em pesquisa realizada com base em depoimentos recebidos durante a produção de sua primeira obra e em sua publicação posterior, denominada "Mal-Estar no Trabalho - Redefinindo o Assédio Moral" (Hirigoyen, 2002), identificando que a origem do assédio moral é bem diversificada e apresentando os tipos de assédio.

A primeira classificação foi denominada vertical descendente e está relacionada à hierarquia. Trata-se do pressuposto mais popular, tendo em vista que o assédio moral é geralmente associado a abusos cometidos pela chefia contra seus subordinados. No entanto, Hirigoyen (2008) afirma que é difícil diferenciar atitudes abusivas vindas da hierarquia, pois a noção de subordinação já vem associada a uma relação de desigualdade, na qual o indivíduo hierarquicamente superior ordena e os subordinados devem obedecer. Ainda nessa perspectiva, conforme Carvalho (2009), esse tipo de assédio caracteriza-se como o mais trivial, em razão da própria natureza da organização do trabalho, a qual é fortemente influenciada pela competitividade e maior lucratividade com menor custo. Assim, a prática do assédio moral, quando realizada pelo próprio empregador ou por um superior hierárquico, "tem por finalidade em regra - eliminar o trabalhador da organização empresarial, forçando uma situação na qual o empregado se demita e/ou abandone o ambiente de trabalho" (Carvalho, 2009, p. 65).

Outra classificação para o assédio moral, inversa à anterior, é o assédio vertical ascendente, ou seja, praticado dos subordinados para os seus superiores, no qual, na maioria dos casos, os agressores agem em grupo. Hirigoyen (2008) destaca que essa modalidade não é tão comum e por vezes nem chega a ser considerada, mas é também prejudicial. Esse tipo de assédio pode se apresentar com dois objetivos: A falsa alegação de assédio sexual, a qual tem o intuito de atentar contra a reputação de uma pessoa e desmoralizá-la; e as reações coletivas, em que existe a cumplicidade de todos os membros que o compõem, para conseguirem a troca do superior hierárquico que lhes foi imposto e que não é aceito pelo grupo (Hirigoyen, 2008). "Essa espécie de terror psicológico pode vir a ser praticada em relação ao superior que extrapola os poderes de 
mando de gestão, adotando posturas autoritárias e arrogantes" (Carvalho, 2009, p. 68).

A última classificação refere-se ao assédio moral misto, que corresponde à prática simultânea de dois ou mais tipos de assédio. Hirigoyen (2008) afirma que são raros os casos de assédio moral horizontal que não são seguidos pelo assédio vertical descendente.

Em síntese, o assédio moral pode ser concebido como as ações que expõem o indivíduo de forma constrangedora e que ocorrem com alguma frequência. Essa situação acontece por parte da chefia para com os subordinados, ou vice-versa, e também entre funcionários que desempenham suas atividades dentro de uma mesma hierarquia, causando, na maioria das vezes, consequências graves para o assediado.

\subsection{Aspectos legais e consequências do assédio moral no Brasil}

São cada vez mais recorrentes na Justiça do Trabalho denúncias e ações envolvendo casos de assédio moral em todo o Brasil. A legislação brasileira proíbe qualquer tipo de coação, abuso ou vantagem ilícita e, ainda que não haja uma legislação específica, existe embasamento legal para essa proibição no texto constitucional, na Consolidação das Leis do Trabalho (CLT), no Código Civil e no Código Penal, que asseguram o ambiente saudável no universo do trabalho.

Atualmente, ainda que não exista uma legislação federal que discorra sobre o assédio moral, como acima mencionado, há vários projetos de lei nos âmbitos municipal, estadual e federal com o intuito de introduzir no Código Penal Brasileiro punições, como detenção e multas, àqueles que se enquadram nessa prática. Nesse aspecto, destaca-se o projeto de Lei n. 4.742/2001, que aguarda apreciação do plenário, proposto pelo deputado Marcos de Jesus, que pretende incluir o Artigo 146-A no Código Penal, Decreto-lei n. 2.848, de 7 de dezembro de 1940, dispondo sobre o crime de assédio moral no trabalho, com a seguinte redação:

"Art. 146-A. Depreciar de qualquer forma e reiteradamente a imagem ou o desempenho de servidor público ou empregado, em razão de subordinação hierárquica funcional ou laboral, sem justa causa, ou tratá-lo com rigor excessivo, colocando em risco ou afetando 
sua saúde física ou psíquica. Pena - detenção de um a dois anos" (Projeto de lei $\mathrm{n}^{\circ}$ 4.742A, 2001, p.1).

É possível citar ainda a Lei n. 8.112, de 11 de dezembro de 1990, a qual discute a aplicação de penalidades aos servidores da União, das autarquias e das fundações públicas federais. O artigo 132, inciso VII, da referida lei, aplica a demissão em casos de "ofensa física, em serviço, a servidor ou a particular, salvo em legítima defesa própria ou de outrem" (Lei n. 8.112, 1990, p. 1). Já a Lei n. 2.949, de 19 de abril de 2002, estabelece sanções à prática de assédio moral aos que compõem a administração pública do Distrito Federal. Destaca-se seu artigo $2^{\circ}$, o qual caracteriza as práticas de assédio moral, como, por exemplo, utilizar-se de palavras ou gestos para desqualificar o indivíduo, exigir o cumprimento de metas utilizando-se de ameaças ou exigir o desenvolvimento de atividades que não condizem com a função do indivíduo (Lei n. 2.949, 2002). Vale também destacar a Lei n. 15.036, de 18 de novembro de 2011, que “dispõe sobre o assédio moral no âmbito da administração pública estadual e seu enfrentamento, visando a sua prevenção, repreensão e promoção da dignidade do agente público no ambiente de trabalho, e dá outras providências" (Lei n. 15.036, 2011, p. 1). Logo no início do texto dessa lei é estabelecida a proibição desse ato e apresenta-se uma definição para as ações que se caracterizam como assédio.

Assim, o Brasil já reconhece o assédio moral como uma forma de violência e, de certa forma, um problema de saúde pública, porém, caminha a passos lentos quando se trata de leis específicas e punições para agressores. Uma das consequências que o assédio moral pode ocasionar à vítima é apresentada por Barreto (2007) como o comprometimento da integridade, da saúde e da vida do trabalhador, tendo em vista que as ações podem evoluir para perturbação mental, incapacidade laborativa, depressão e até mesmo a morte do assediado. Sem dúvidas, a vítima dos atos de assédio é quem sofre os maiores danos. Para Maciel (2015), o assediado pode sofrer com transtornos mentais e de comportamento, sofrer redução na sua capacidade de concentração e memorização, baixa autoestima, dificuldade na tomada de decisões, isolamento constante, além de problemas fisiológicos, como distúrbios alimentares, disfunção do aparelho digestivo, hipertensão e dores musculares. 


\section{O contexto da atuação do profissional de secretariado executivo}

Diante da necessidade do mercado de profissionais capacitados, os profissionais de secretariado executivo precisaram adaptar-se às novas exigências e evoluir na profissão, que teve suas características modificadas, uma vez que esse profissional deixou de ser elemento de apoio da chefia para assumir novos desafios (Rodrigues et al., 2016). No âmbito das leis, os profissionais de secretariado executivo possuem regulamentação e definição de atividades estabelecidas pela Lei n. 7.377, de 30 de setembro de 1985, complementada pela Lei 9.261, de 10-01-1996. De acordo com a referida Lei, considera-se como profissional de secretariado executivo quem possui formação em curso técnico ou superior e aqueles que comprovarem experiência na área conforme especificações da lei. Assegura também o registro profissional sob responsabilidade da Superintendência Regional do Trabalho e Emprego (SRTE) (Lei n. 7.377, 1985).

A partir desses avanços, as atividades desempenhadas e o instrumentário utilizado pelos secretários acompanharam os anos de grandes mudanças pelas quais a profissão passou. Os escritórios contam hoje com vários aparelhos eletrônicos que dinamizam a rotina diária de trabalho e, portanto, essa foi mais uma adaptação pela qual os profissionais de secretariado passaram: Saber lidar com as novas tecnologias. O secretário executivo tem papel primordial que envolve a chefia e os demais colaboradores da organização. Por ser um profissional que está sempre em convívio direto com o executivo, muitas vezes colabora com as decisões e é responsável por gerenciar e administrar informações (Leal, 2014).

Esse cenário é consequência de diversas transformações que ocorreram na área secretarial, fazendo com que esse profissional passe a assumir postos de trabalho que permeiam atividades cada vez mais complexas (Muller \& Sanches, 2014). Desse modo, os profissionais de secretariado executivo têm conhecimento de grande parte das informações internas e externas à empresa e são capazes de "intervir nos processos decisórios, identificar dificuldades e solucioná- 
las, analisar e interpretar informações, trabalhar em equipe e atuar como agente de mudanças" (Leal, 2014, p. 67).

O secretário executivo busca adaptar-se às novas exigências do mercado, agregando conhecimentos por meio de capacitação constante, para que, assim, seja capaz de acompanhar as novas demandas e ser merecedor da confiança que lhe foi dada, buscando o diferencial perante outros profissionais (Santos \& Moretto, 2011). Destaca-se que a formação acadêmica em Secretariado Executivo incentiva o desenvolvimento de habilidades e capacidades intelectuais, práticas profissionais, dinamismo, comportamento, postura, ética no trabalho, entre outros conhecimentos.

\subsection{A ética e os estereótipos relacionados ao profissional de secretariado executivo}

O comportamento ético é muito valorizado no mundo corporativo. Não seria diferente para com os profissionais de secretariado executivo, já que estes devem agir com discrição nas relações de trabalho e lidam com informações extremamente sigilosas. Rodrigues e Oliveira (2012) mostram que o conceito de ética foi amplamente difundido em todos os âmbitos da vida do ser humano, inclusive no profissional, o que levou muitas categorias a desenvolverem seu próprio código de ética com o intuito de estabelecer as condutas de cada profissional, levando o homem a refletir sobre as suas ações e exercer o respeito ao seu semelhante no decorrer do exercício de sua profissão.

O secretariado executivo possui seu Código de Ética, publicado em 7 de julho de 1989 no Diário Oficial da União (DOU), que é o instrumento que guia as relações profissionais e orienta a conduta no ambiente profissional, além de caracterizar direitos e deveres. É importante destacar que o Código de Ética dessa categoria traz uma série de relações que o secretário deve manter durante o exercício profissional com a empresa, com as entidades da categoria e com os próprios secretários (Brasil, 1989).

Nesse sentido, Whitaker e Cavalcanti (2010) destacam que o perfil do secretário executivo se caracteriza, para além de gestão de tempo, recursos e informações, pelo sigilo,

\begin{tabular}{|l|l|l|l|l|l|} 
(C) Revista SCRIBES & Viçosa, $M G$ & v. 1 & n. 1 & Julho/2020 & ISSN 2675-4401 \\
\hline
\end{tabular}


sendo este um componente de valor estratégico para o que a organização se propõe, podendo esse profissional contribuir e muito para a prática do exercício desse direito, exigindo de si mesmo e das pessoas com quem se relaciona o cumprimento desse dever.

Essa relação da ética por parte do profissional de secretariado executivo muitas vezes não é recíproca, tendo em vista os estereótipos estabelecidos. Em um cenário em que esse profissional faz parte de um conjunto de profissões muito visadas no ambiente corporativo, ele também é suscetível a sofrer casos de assédio moral e receber ações abusivas por parte de seus executivos ou de outros públicos ligados à organização. Vale ressaltar que os estereótipos negativos relacionados ao secretariado devem ser constantemente repreendidos para que a profissão seja vista com o respeito e o merecimento necessários e para que os profissionais sejam reconhecidos por seu desempenho e competência, recebendo a devida remuneração com base nos acordos firmados por seus sindicatos, independente de qual gênero desenvolva as atividades.

A existência do estereótipo aplicado ao secretário pode ser mais bem compreendida se for analisado o contexto histórico da profissão. A primeira pessoa a escrever em público numa máquina de datilografar - símbolo, na época, associado à profissão de secretário - foi uma mulher, Lilian Sholes. Em 30 de setembro de 1950, foi promovido o primeiro concurso de datilógrafos que teve a presença maciça de mulheres e passou-se a comemorar o Dia da Secretária nessa data, visto que a maioria das mulheres presentes atuava como secretária (Terra, Uchimura, \& Scopinho, 2012, p. 79).

Ainda no que tange aos estereótipos, Paim e Pereira (2010, p. 32) afirmam que "com a responsabilidade de manter sigilo sobre informações cruciais, o exemplo do escriba remonta à origem etimológica do termo - secretária: Aquela que guarda segredo".

Discutir e apresentar aos demais colaboradores e à sociedade o Código de Ética é tarefa essencial para os secretários executivos e sindicatos, bem como para os discentes, tendo em vista que estes serão futuros profissionais e deverão atuar eticamente no mercado de trabalho, de forma a combater os estereótipos que cercam a área secretarial e sabendo como agir diante de situações ou empresas nas quais a ética não se faz presente. 


\section{Metodologia}

O presente estudo tem abordagem qualitativa e quantitativa. Nessa perspectiva, quanto aos objetivos da pesquisa, estes têm caráter descritivo. Segundo Gil (2008), as pesquisas descritivas têm como finalidade principal a descrição das características de determinada população ou fenômeno.

O universo da pesquisa foi composto por profissionais de Secretariado Executivo de todo o Brasil. A amostra desta pesquisa consiste em 139 profissionais com formação em Secretariado Executivo, sendo uma profissional de Secretariado Executivo que sofreu assédio moral em seu ambiente de trabalho, uma representante que integra órgãos representativos da classe secretarial e outros 137 que participaram via questionário. O quadro a seguir explicita a justificativa pela escolha da amostra.

\section{Quadro 3 - Delimitação e justificativa da amostra}

\begin{tabular}{|c|c|}
\hline DELIMITAÇÃO & JUSTIFICATIVA \\
\hline $\begin{array}{l}\text { Profissionais de Secretariado Executivo } \\
\text { com formação superior na área }\end{array}$ & $\begin{array}{l}\text { Para fundamentar a pesquisa de campo } \\
\text { realizada por questionário, buscando } \\
\text { conhecer o cenário do assédio moral } \\
\text { junto a profissionais de Secretariado } \\
\text { Executivo de todo o Brasil. }\end{array}$ \\
\hline $\begin{array}{l}\text { Profissional de Secretariado Executivo que } \\
\text { sofreu assédio moral }\end{array}$ & $\begin{array}{l}\text { Para fundamentar a pesquisa de campo } \\
\text { realizada por entrevista, a fim de } \\
\text { aprofundar em um caso específico e } \\
\text { concreto dentro da temática estudada. } \\
\text { Tendo em vista também que o } \\
\text { questionário não permite maior }\end{array}$ \\
\hline
\end{tabular}




\begin{tabular}{|l|l||}
\hline & $\begin{array}{l}\text { aprofundamento e a entrevista possibilita } \\
\text { perceber maiores informações. }\end{array}$ \\
\hline \hline Presidente do Sindicato de Secretários e & Para verificar o posicionamento de uma \\
Secretárias do Estado do Ceará & entidade representativa da categoria \\
(SINDISECE) e diretora de Seguridade & profissional de Secretariado Executivo, \\
Social e Assuntos Jurídicos da Federação & avaliando como o órgão se posiciona com \\
Nacional das Secretárias e Secretários & relação ao assédio moral. \\
(FENASSEC) & \\
\hline
\end{tabular}

Fonte: Elaborado pelas autoras (2017).

Assim, foram feitas diferentes abordagens junto à amostra da pesquisa delimitada acima. A coleta de dados com profissionais de Secretariado de todo o Brasil feita por questionário foi realizada no período de 20 de abril a 20 de maio de 2017. A entrevista com a secretária que sofreu assédio moral foi realizada no dia 24 de novembro de 2016 e teve duração aproximada de uma hora. A entrevista realizada com a representante sindical foi realizada no dia 12 de novembro de 2016 e teve também duração aproximada de uma hora.

A estratégia de pesquisa utilizada foi a pesquisa de campo. Conforme Yin (2005), a estratégia de uma pesquisa define como os dados serão coletados e analisados. A pesquisa de campo deu-se em três fases. Na primeira fase, foi desenvolvida uma entrevista narrativa, que, conforme Schraiber (1995), é a externalização do pensamento de forma oral e apropriada para o estudo qualitativo. Essa entrevista foi realizada com uma profissional da área de Secretariado Executivo. Na segunda fase, foi realizada também uma entrevista com uma representante do Sindicato das Secretárias e Secretários do Estado do Ceará (SINDSECE). Na terceira fase, a fim de fortalecer a identificação da temática analisada, foram aplicados questionários para profissionais formados em secretariado executivo de todo o Brasil.

Para a realização da pesquisa, foram utilizados dois instrumentos de coleta de dados: $\mathrm{O}$ questionário e a entrevista narrativa. A coleta de dados por meio de questionários foi feita no 
período de 20 de abril a 20 de maio de 2017 e as entrevistas foram realizadas no período de 1 a 30 novembro de 2016. O questionário foi feito a partir do Google Formulários e o link foi enviado via e-mail aos egressos dos cursos de Secretariado Executivo da Universidade Federal do Ceará, conforme lista disponibilizada pela coordenação do curso (com 585 contatos, mas apenas 359 com e-mail) e disponibilizado em grupos de Facebook e WhatsApp compostos por profissionais de Secretariado Executivo do Brasil, já que não foi possível o acesso à lista de egressos em cursos de outras localidades do Brasil. O questionário foi composto por 14 perguntas, sendo três de múltipla escolha, nove objetivas e duas questões discursivas.

Em relação aos grupos, foi delimitado o envio somente para grupos com regras definidas e administrados por profissionais formados na área de secretariado executivo, a fim de garantir a validade e confiabilidade da pesquisa, sendo um grupo no Facebook ("Secretariado Executivo Brasil”, com 6.461 membros até o momento da pesquisa) e um no WhatsApp ("Secretariado Executivo", com 113 membros até o momento da pesquisa). Ambos são privados e só aceitam profissionais de secretariado executivo. Obteve-se um retorno de 137 respostas via questionário.

Acerca das entrevistas, a primeira foi realizada com uma secretária executiva, a qual não autorizou sua identificação no estudo. Ela é formada pela Universidade Federal do Ceará em Secretariado Executivo e atua em uma autarquia federal. Inicialmente, foi definido um roteiro que serviu apenas para nortear a entrevista, composto por oito perguntas abertas, sendo algumas adaptadas diante das respostas e reações da entrevistada durante suas declarações. Todo o áudio da entrevista foi gravado por um aparelho celular e esta durou cerca de uma hora. Logo após houve a transcrição fidedigna.

Com relação à segunda entrevista, esta foi realizada com uma representante sindical do SINDSECE, que autorizou a publicidade da sua identidade na pesquisa. A entrevistada tem forte influência na área de secretariado executivo e está há mais de 40 anos atuando no mercado de trabalho. A entrevistada pôde relatar suas percepções sobre o assédio moral e o posicionamento dos órgãos competentes dos quais integra. Foi elaborado previamente um roteiro de entrevista, estruturado em oito questões subjetivas. 
Após a coleta de dados via questionários enviados, a análise dos dados coletados foi feita utilizando a metodologia estatística descritiva que, conforme Hair et al. (2005), envolve, durante a coleta, processamento e interpretação das informações e a apresentação de dados numéricos e percentuais. A análise das entrevistas foi baseada na análise de conteúdo. Essa metodologia não estaciona na interpretação, pois vai além de seus limites; "também não procura um sentido verdadeiro através de uma chave de interpretação. Não há esta chave, há método, há construção de um dispositivo teórico. Não há uma verdade oculta atrás do texto" (Orlandi, 2001, p. 26). Assim, a seguir está explanada a seção que detalha os resultados da pesquisa.

\section{Análise e discussão dos resultados}

A análise de dados está dividida em duas etapas. A primeira contempla a análise referente aos questionários aplicados com profissionais de secretariado executivo acerca da temática do assédio moral. A segunda etapa é referente à análise das entrevistas com a profissional de secretariado executivo vítima de assédio moral e com a presidente do SINDSECE.

\subsection{Análise dos questionários}

O questionário aplicado com os profissionais de secretariado executivo foi dividido nas seguintes etapas: Perfil do participante, ocorrência de assédio moral com profissionais de secretariado e consequências do assédio moral. A partir da análise dos 137 retornos de respostas, verificou-se o perfil dos profissionais, conforme o quadro abaixo:

Quadro 4 - Perfil dos profissionais da pesquisa

\begin{tabular}{|c|c|c|c|c|c|c|}
\hline \multicolumn{2}{|c|}{ Sexo } & \multicolumn{3}{|c|}{ Idade } & \multicolumn{2}{|c|}{ Formação } \\
\hline Feminino & Masculino & $\begin{array}{c}\text { Entre } 20 \text { e } \\
29 \text { anos }\end{array}$ & $\begin{array}{c}\text { Entre } 30 \\
\text { e } 40\end{array}$ & $\begin{array}{l}\text { Mais de } \\
41 \text { anos }\end{array}$ & Bacharelado & Tecnólogo \\
\hline
\end{tabular}

\begin{tabular}{|c|c|c|c|c|c} 
(C) Revista SCRIBES & Viçosa, $M G$ & v. 1 & n. 1 & Julho/2020 & ISSN 2675-4401 \\
\hline
\end{tabular}




\begin{tabular}{|c|c|c|c|c|c|c|}
\hline & & & anos & & & \\
\hline $94 \%$ & $6 \%$ & $36 \%$ & $48 \%$ & $16 \%$ & 88,3 & $11,7 \%$ \\
\hline
\end{tabular}

Fonte: Dados da pesquisa de campo (2017).

Com a finalidade de conhecer ainda mais o perfil dos participantes da pesquisa, foi indagado a eles acerca de sua empregabilidade e período de atuação na área secretariado executivo e foram obtidas as informações do quadro abaixo:

Quadro 5 - Empregabilidade dos profissionais da pesquisa

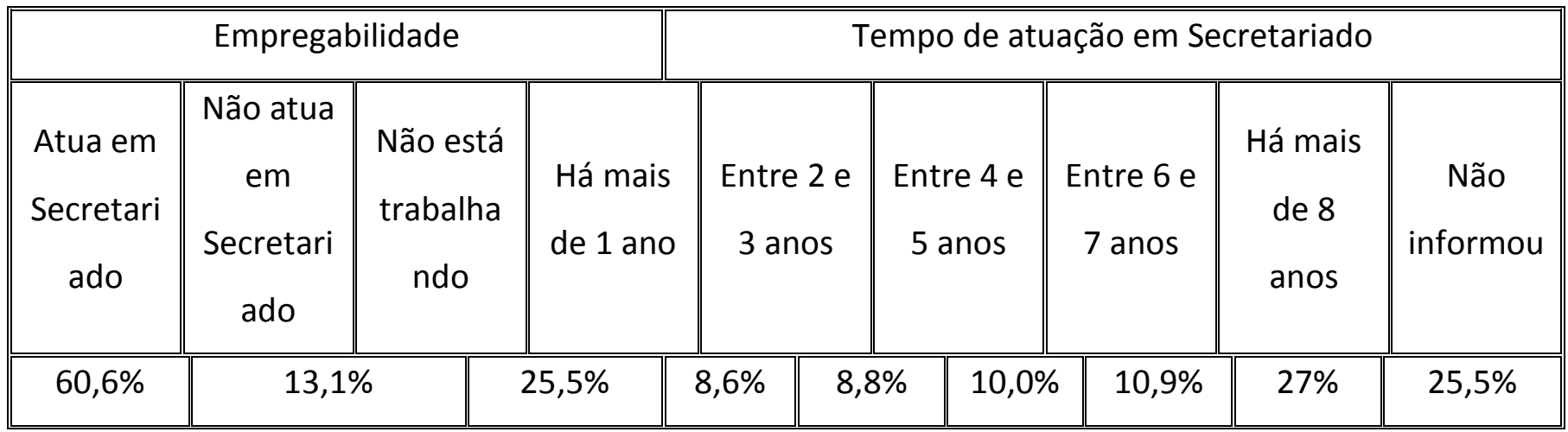

Fonte: Dados da pesquisa de campo (2017).

Percebe-se, observando o quadro acima, que a maioria dos profissionais que está empregada atua na área de secretariado executivo e com um período de tempo superior a oito anos (27\%), o que pode revelar uma experiência profissional consolidada na área. Além disso, procurou-se conhecer o local em que moram os profissionais que participaram da pesquisa. 


\section{Gráfico 1 - Local de moradia dos profissionais da pesquisa}

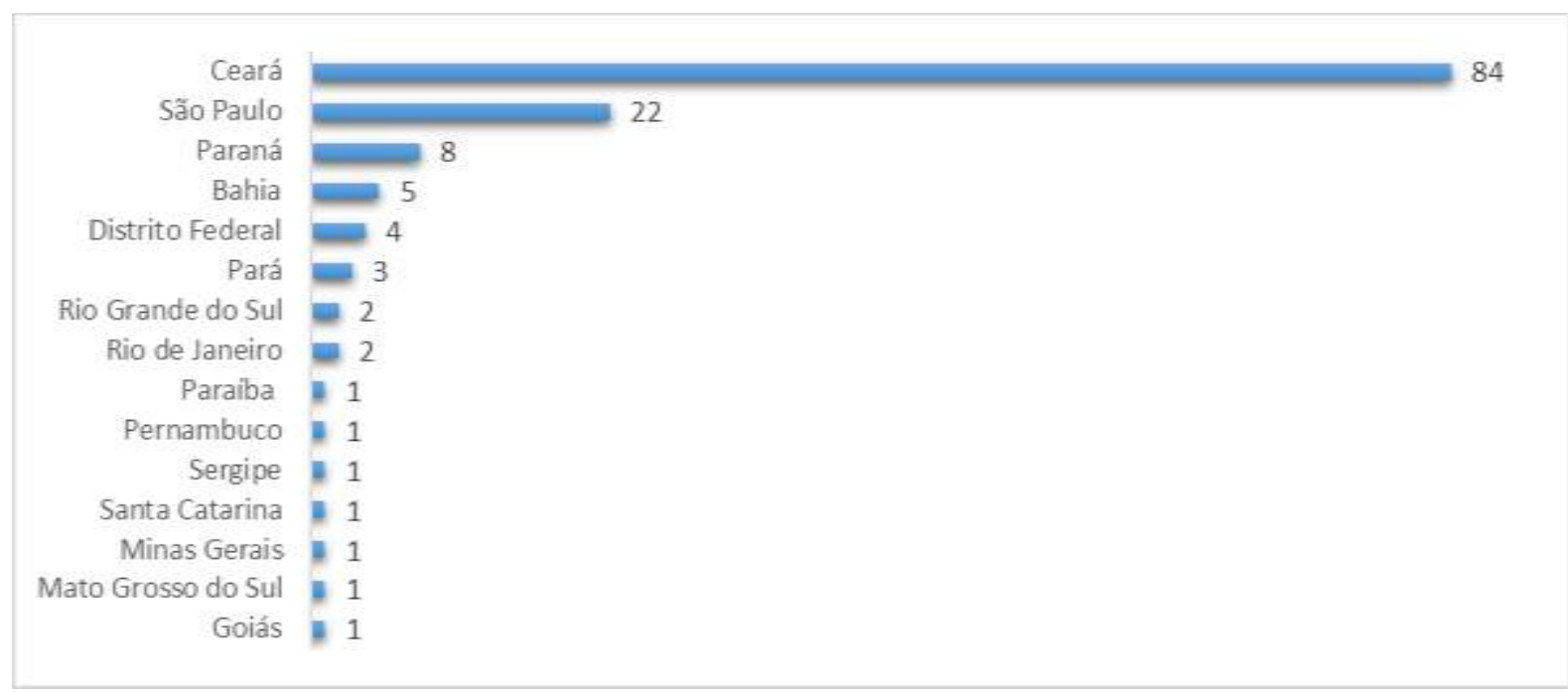

Fonte: Dados da pesquisa de campo (2017).

Percebe-se que a maioria é predominante do Ceará, o que pode ser justificado pelo envio do e-mail à lista de egressos do curso de secretariado executivo da Universidade Federal do Ceará (UFC). Em outro âmbito, é positivo ver que pelo menos um profissional de cada região participou da pesquisa. A seguir, tem-se uma análise acerca da ocorrência de assédio moral com profissionais de secretariado executivo.

\subsection{Ocorrência de assédio moral com profissionais de secretariado executivo}

No âmbito da atuação em secretariado executivo, procurou-se saber dos profissionais que participaram da pesquisa quantos casos de profissionais de secretariado executivo que sofreram assédio moral eles conheciam. O gráfico abaixo mostra o percentual de profissionais que conhecem casos de assédio moral, tendo em vista que apenas 14\% afirmaram não conhecer nenhum caso de assédio moral com profissionais de secretariado executivo, percentual alarmante e que fica evidenciado nas informações do gráfico abaixo. 


\title{
Gráfico 2 - Conhecimento de casos de assédio moral com Profissionais de
}

\section{Secretariado}

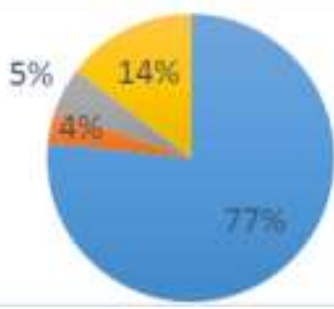

\author{
- Entre 1 e 4 casos \\ Mais de oito casos \\ Entre cinco e sete casos \\ 피 Não conhece nenhum caso
}

Fonte: Dados da pesquisa de campo (2017).

Como pode ser observado no gráfico, apenas $14 \%$ dos profissionais não conhecem casos de assédio moral com secretários, o que demonstra uma situação preocupante, observados os demais percentuais em que $77 \%$ conhece entre 1 e 4 casos. Esse cenário demonstra que é necessário um maior aprofundamento dessa temática que é o assédio moral, já que, conforme visto por Martiningo e Siqueira (2015), seus efeitos têm impactos que vão além do profissional e se externam para a sociedade em geral.

Em seguida, questionou-se aos participantes se eles já haviam sofrido assédio moral, seja na experiência de trabalho atual ou em anteriores. Os dados podem ser observados no gráfico abaixo.

\section{Gráfico 3 - Assédio moral entre os profissionais de Secretariado Executivo}

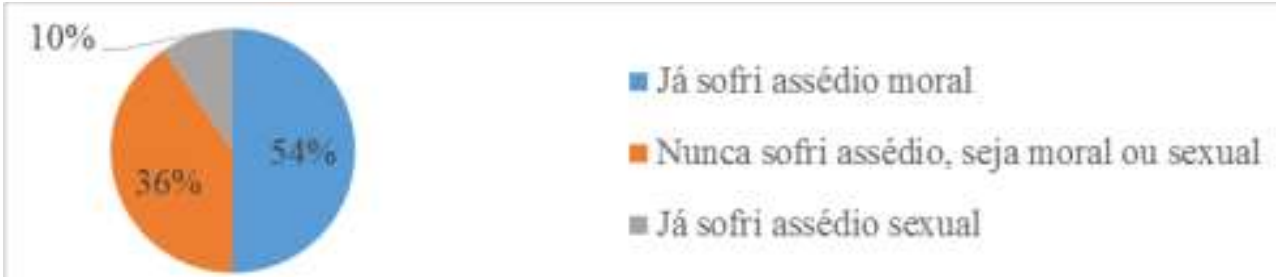

Fonte: Dados da pesquisa de campo (2017).

Verifica-se que a maioria de $64 \%$ sofreu assédio, dentre os quais $54 \%$ foi assédio moral e 10\%, assédio sexual. Apenas 36\% afirmaram não ter sofrido nenhum tipo de assédio. Sabendo que não há nada que justifique a prática do assédio, destaca-se o que foi afirmado por Santiago e

\begin{tabular}{|l|l|l|l|l|l} 
(C) Revista SCRIBES & Viçosa, $M G$ & v. 1 & n. 1 & Julho/2020 & ISSN 2675-4401
\end{tabular}


Santos (2009, p. 69) sobre o fato de que, uma vez que o profissional de secretariado executivo lida com uma diversidade de setores na organização, é possível que ele esteja mais suscetível a sofrer assédio.

Foi questionado aos respondentes que tivessem afirmado ter sofrido assédio moral, ou seja, $54 \%$, conforme o gráfico 3, há quanto tempo ocorreu esse assédio. Assim, o gráfico abaixo mostra esses percentuais.

\section{Gráfico 4 - Período em que ocorreu o assédio moral entre os profissionais da}

\section{pesquisa}

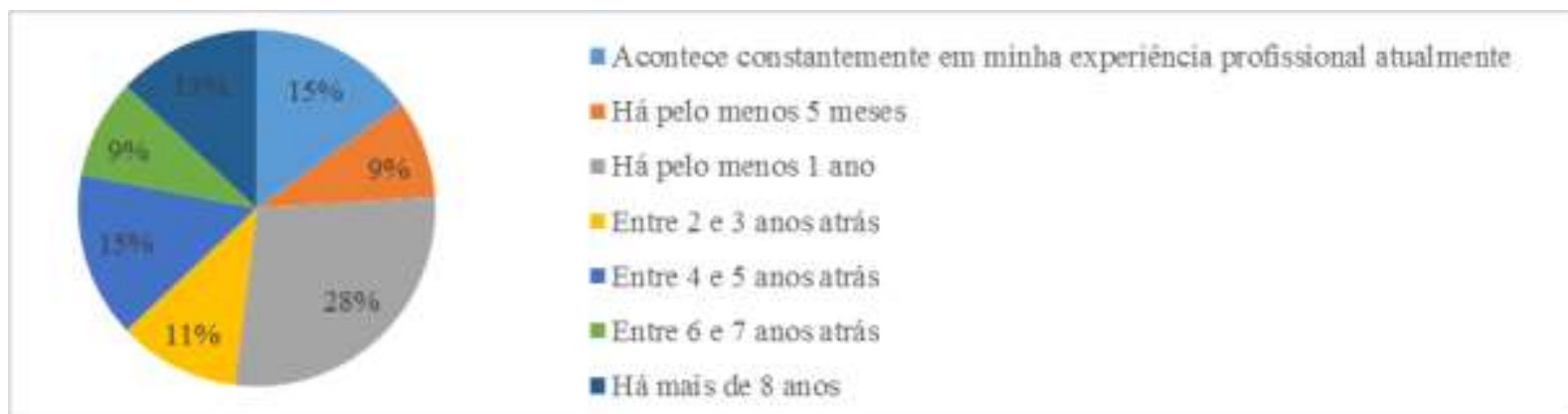

Fonte: Dados da pesquisa de campo (2017).

Como pode ser observado, o maior percentual mostra o período de ocorrência do assédio há pelo menos um ano atrás $(28 \%)$, além do percentual de $15 \%$, que correspondem ao assédio na experiência atual de trabalho. Esses dados reforçam a situação alarmante de que o assédio em secretariado executivo necessita ser debatido, conforme Santiago e Santos (2009).

Procurou-se também conhecer a periodicidade dessas situações de assédio moral. O gráfico abaixo a demonstra. 


\section{Gráfico 5 - Periodicidade do assédio moral entre os profissionais pesquisados}

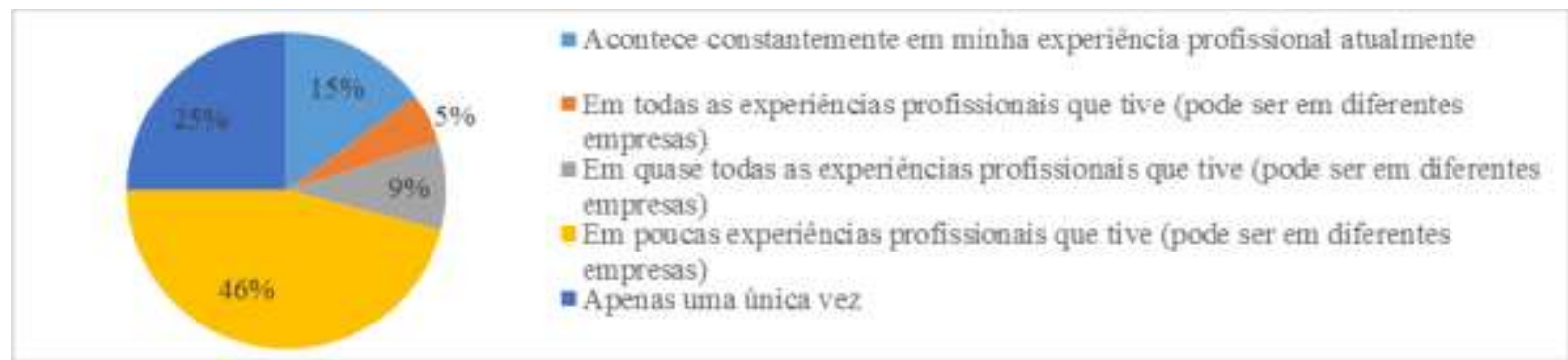

Fonte: Dados da pesquisa de campo (2017).

Conforme pode ser observado, o gráfico mostra que o maior percentual representa a frequência do assédio em poucas experiências profissionais (46\%) e, em seguida, ocorrendo uma única vez (25\%). Contudo, ainda é preocupante que existam percentuais que demonstrem que isso ocorre com alguns profissionais em todas (5\%) e em quase todas (9\%) experiências profissionais, além do percentual de $15 \%$ daqueles que passam constantemente por esse tipo de situação. Conforme visto no referencial teórico, o contexto da profissão de secretariado desde os primórdios passou por diversos tipos de estereótipos que foram sendo relacionados ao gênero e que pode estar relacionado com a prática do assédio moral (Terra et al., 2012).

Questionou-se aos profissionais como reagiram ao assédio moral, e a eles foram oferecidas algumas opções: Somente marcar ou relatar informação que não estivesse entre os tópicos. Obteve-se o gráfico abaixo: 


\section{Gráfico 6 - Reação ao assédio moral dos profissionais pesquisados}

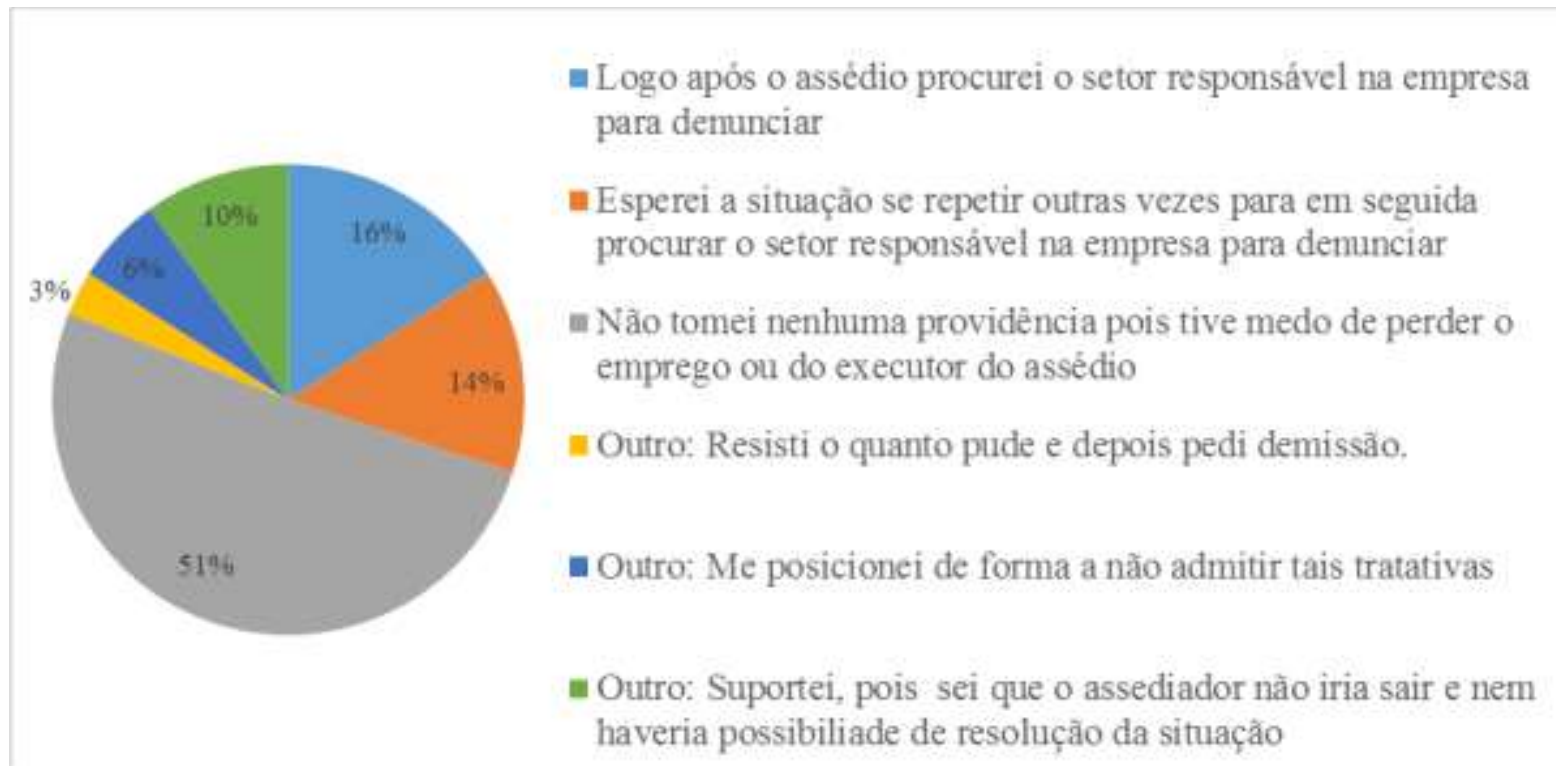

Fonte: Dados da pesquisa de campo (2017).

Os dados do gráfico revelam que $51 \%$ dos participantes não tomaram nenhuma providência em relação ao assédio moral por medo de perder o emprego ou por medo do executor do assédio. O pequeno percentual de $16 \%$ e $14 \%$ mostra que os respondentes buscaram denunciar o assédio moral logo após o assédio ou após ele se repetir, respectivamente. Ainda com relação aos profissionais que sofreram assédio moral, foi solicitado que indicassem, a partir de sua experiência, por quem esse assédio foi praticado, e, na questão, foram disponibilizadas várias opções e os respondentes poderiam marcar mais de uma opção de resposta. O gráfico abaixo explana sobre esse cenário. 
Gráfico 7 - Por quem é praticado o assédio aos profissionais pesquisados

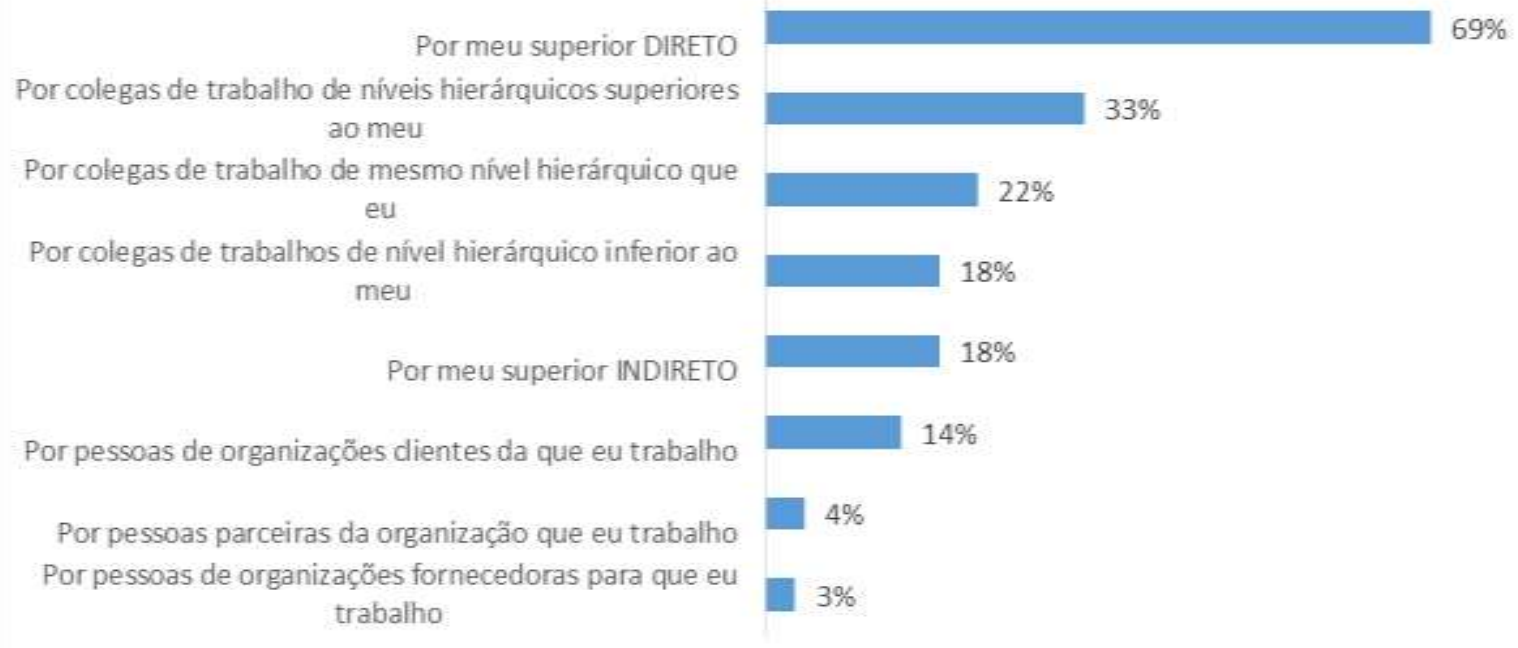

Fonte: Dados da pesquisa de campo (2017).

Observando que cada profissional poderia citar mais de uma opção, tendo em vista que o assédio não necessariamente pode ser praticado por uma única pessoa, percebe-se, observando o gráfico acima, que $69 \%$ dos profissionais que sofreram assédio moral afirmaram que ele foi praticado por seu superior direto e $33 \%$ por colegas de trabalho de nível superior ao seu.

De maneira geral, pode ser observado que a maioria dos tipos de assédio citados por Hirigoyen (2008) no referencial teórico estiveram evidentes no gráfico. Contudo, os profissionais citaram também essa prática sendo cometida por outros públicos da organização, como clientes $(14 \%)$, organizações fornecedoras $(4 \%)$ e parceiras $(3 \%)$, que, apesar de aparecerem em menor percentual, também praticam assédio moral. A seguir, poderão ser observadas as principais consequências da prática de assédio moral a partir das afirmações dos participantes deste estudo.

\subsection{Consequências do assédio moral com profissionais de secretariado executivo}

No que concerne às consequências do assédio moral, foi solicitado somente aos profissionais de secretariado executivo que sofreram assédio moral que citassem algumas de suas

\begin{tabular}{|l|l|l|l|l|l|} 
(C) Revista SCRIBES & Viçosa, $M G$ & v. 1 & n. 1 & Julho/2020 & ISSN 2675-4401 \\
\hline
\end{tabular}


consequências, em uma questão na qual os participantes poderiam marcar mais de uma opção, conforme o gráfico abaixo:

\section{Gráfico 8 - Consequências do assédio moral}

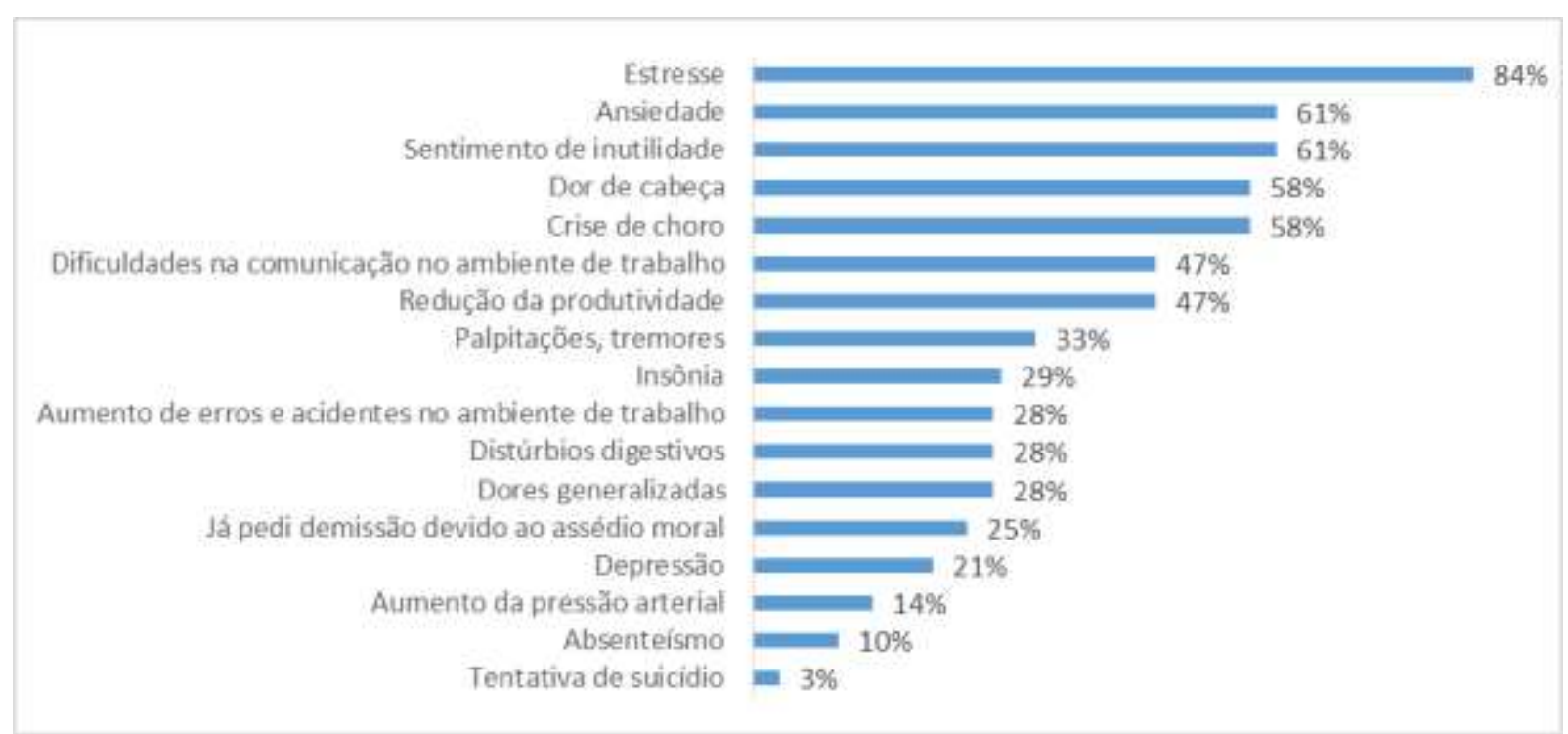

Fonte: Dados da pesquisa de campo (2017).

Como pode ser observado no gráfico, todos os itens foram citados pelos profissionais e alguns deles foram expressivamente mais apontados, como o estresse, citado por $84 \%$ dos participantes. Conforme visto no embasamento teórico desta pesquisa, a prática do assédio moral ocasiona graves consequências para as vítimas, em três níveis: Problemas físicos, emocionais e psicológicos, que foram identificados ao longo das opções mostradas no gráfico acima e que também foram destacadas por Carvalho (2009), Barreto (2007) e Maciel (2015).

Para finalizar a investigação junto a todos os profissionais que participaram da pesquisa, foi solicitado que eles destacassem quais medidas poderiam ser eficientes se adotadas pelas organizações para o combate a prática do assédio moral. Assim, foram elencadas algumas opções para marcação e uma outra para que os respondentes pudessem expressar sua opinião de forma mais clara. O quadro abaixo destaca as afirmações e os percentuais em que cada uma foi citada de acordo com os profissionais que participaram da pesquisa. 
Quadro 6 - Medidas que podem ser adotadas pelas organizações para o combate ao assédio moral

\begin{tabular}{|l||l||}
\hline \multicolumn{1}{|c|}{ Medidas } & $\%$ \\
\hline \hline $\begin{array}{l}\text { A área de Recursos Humanos deve deixar claro que suas portas sempre } \\
\text { estarão abertas para ouvir os funcionários sobre denúncias, garantindo o } \\
\text { sigilo dos fatos relatados. }\end{array}$ & $49 \%$ \\
\hline $\begin{array}{l}\text { Adoção de um Código de Ética que expresse claramente a postura da } \\
\text { empresa em relação ao assédio moral e quais providências serão adotadas, } \\
\text { caso algum fato ocorra. }\end{array}$ & $47 \%$ \\
\hline \hline \begin{tabular}{l} 
Utilizar os canais internos de comunicação no combate ao assédio moral \\
\hline \hline $\begin{array}{l}\text { Ações educativas e estímulo à paz nos relacionamentos em todos os níveis } \\
\text { Pesquisa de clima organizacional }\end{array}$
\end{tabular} & $40 \%$ \\
\hline $\begin{array}{l}\text { A cultura organizacional forte } \\
\text { Adoção de políticas contra o assédio }\end{array}$ & $37 \%$ \\
\hline \hline $\begin{array}{l}\text { Transmitir informações aos colaboradores sobre seus direitos trabalhistas } \\
\text { como também os direitos universais do cidadão } \\
\text { funcionários formadores de opinião, que tenham facilidade de comunicação } \\
\text { com os demais pares } \\
\text { Realização de palestras em eventos realizados pela organização como } \\
\text { treinamentos, encontros comemorativos é uma alternativa para esclarecer } \\
\text { garantam a integridade dos colaboradores. O mesmo comitê pode, por }\end{array}$ & $30 \%$ \\
\hline $\begin{array}{l}\text { Para combater o assédio moral, a organização pode criar um comitê } \\
\text { permane e que tenha o objetivo de desenvolver procedimentos que }\end{array}$ & \\
\hline
\end{tabular}


aos colaboradores o que significa assédio moral e as consequências que pode gerar à empresa, ao assediador e à vítima.

Outro: Consciência de todos pelo respeito ao colega

Fonte: Dados da pesquisa de campo (2017).

Conforme pode ser observado no quadro acima, o item que obteve mais retorno dos participantes está relacionado ao posicionamento da organização em demonstrar que existem canais de reclamação e que estes estão disponíveis para atender denúncias de assédio moral (49\%). Fazendo relação com esse item, percebe-se que ele pode ser justificado pelo pequeno percentual de profissionais que, como apresentado no Gráfico 5, procuraram o setor responsável para realizar uma denúncia após ter sofrido assédio moral.

\subsection{Análise das entrevistas}

Nesta etapa da pesquisa foram analisadas as entrevistas realizadas com uma profissional de Secretariado Executivo que sofreu assédio moral e com uma representante do Sindicato das Secretárias e Secretários do Estado do Ceará - SINDSECE.

\subsection{Análise da entrevista com a profissional de Secretariado Executivo vítima de assédio moral}

Antes de dar início à entrevista, foi informado à profissional o objetivo da pesquisa, da qual a mesma aceitou participar, solicitando que a empresa na qual trabalha e sua identidade não fossem reveladas. Assim sendo, ela será identificada apenas como "entrevistada".

Primeiramente, foi solicitado à entrevistada que falasse um pouco sobre ela e sobre o trabalho que desempenha. A profissional afirmou ser formada em Secretariado Executivo pela Universidade Federal do Ceará, exercendo o cargo atualmente de assessora de presidência de uma autarquia. As atividades que desenvolve são todas as correlatas ao secretariado executivo e

\begin{tabular}{|l|l|l|l|l|l} 
(C) Revista SCRIBES & Viçosa, $M G$ & v. 1 & n. 1 & Julho/2020 & ISSN 2675-4401 \\
\hline
\end{tabular}


mais algumas das áreas administrativa e financeira.

No segundo momento, foi solicitado que a entrevistada relatasse uma situação de assédio moral já vivenciada. Assim, relatou que o assédio ocorreu a partir do momento em que ela negou, uma única vez, a realização de uma atividade que não poderia ser realizada, ou seja, que de fato não era permitida. A profissional de nível hierárquico superior a quem a entrevistada tinha negado a realização da atividade relatou o ocorrido de forma a distorcer os fatos para o superior imediato da profissional de Secretariado, causando uma situação antiética e prejudicial. Neste ponto, reforça-se o que foi destacado por Maciel (2015) sobre algumas possíveis justificativas para a prática do assédio moral como a relação de trabalho e o senso de superioridade.

Com relação a outras situações de assédio, foi questionado qual era o nível hierárquico de profissionais que já haviam assediado a entrevistada em outros possíveis momentos e esta afirmou que sempre ocorreu com pessoas em cargos de nível superior ao dela. Quando questionado o seu ponto de vista sobre a origem desses problemas e as causas do assédio, a entrevistada afirmou ser por falta de profissionalismo e ego elevado dos assediadores, por estarem em funções superiores à dela. Esse cenário reforça o exposto pela pesquisa de campo realizada com profissionais de todo o Brasil acerca de quem pratica o assédio, em que se percebeu que, na maioria dos casos, este é perpetrado por profissionais de nível de hierarquia superior ao do profissional de secretariado executivo. Acerca da reação da entrevistada nas situações em que foi vítima, esta afirmou que já ocorreram momentos de choro, de pedir demissão quatro vezes do emprego atual e ter esses pedidos negados. A entrevistada relatou que desenvolveu um autocontrole maior para lidar com a situação, que afirmou ser muito ruim, pois perde-se totalmente o equilíbrio, principalmente diante de injustiças.

Sobre as consequências do assédio moral sofrido na vida profissional e pessoal, a entrevistada relatou que os impactos estão relacionados a sentir-se incompetente, deixar de acreditar no próprio trabalho, surgimento de crise de ansiedade, que a levou a fazer tratamento psicológico, além de o estresse desencadear algumas doenças físicas. A entrevistada afirmou estar sofrendo com pressão alta, sentindo dores intensas, e que teve suspeita de neuralgia do 
trigêmeo (dor crônica que afeta o nervo da face). Após o seu último pedido de demissão, a entrevistada afirmou ter relatado os fatos ocorridos ao seu superior direto, o que lhe proporcionou um maior alívio. Por fim, foi indagado à profissional se, pelo fato de ser secretária, ela acha que está mais vulnerável a sofrer assédio moral do que a outras pessoas. A entrevistada afirmou que sim, como se pode observar: "Existe um preconceito muito grande ainda, porque o secretário é sempre associado a sombra ou ao cumpridor de ordens, somente. Só que, eles exigem muito mais do que isso, então se a gente fosse só um cumpridor de ordens e que a gente não precisasse pensar, o nosso trabalho seria muito mais fácil. Só que quando eles exigem que a gente pense, que a gente seja gestora, que a gente seja assessora, que a gente pense diante deles, eles não tratam como tal profissional, gerando um desconforto muito grande na gente. Então sim, há um preconceito muito grande com o secretariado" (Entrevistada, 2016).

Assim, ela complementou afirmando que, infelizmente, muitos gestores ainda pensam que secretário é aquele mesmo profissional da década de 1970 e 1980, sendo que as atividades mudaram e evoluíram. Percebe-se, então, que a entrevistada relatou uma situação que é comum em sua vivência. Através da entrevista, foi possível a identificação das possíveis causas para esse tipo de agressão, a verificação se esse fenômeno ocorre com o secretário executivo principalmente pelos estereótipos que estão relacionados a esta profissão e a constatação se essa prática causou alguma consequência para a vítima, nas questões psicológicas, profissionais, pessoais e de saúde entre outros. De maneira geral, constata-se o que foi dito no referencial por Terra, Uchimura e Scopinho, (2012), Santiago e Santos (2009) e Paim e Pereira (2010, p. 32) sobre os motivos que levam à prática do assédio e sua relação com o trabalho do profissional de secretariado executivo.

\subsection{Análise da entrevista com a representante sindical dos profissionais de secretariado executivo}

Antes de dar início à realização da entrevista, destaca-se que a participante autorizou a inserção do conteúdo na análise de dados desta pesquisa. Na entrevista com a representante

\begin{tabular}{|l|l|l|l|l|l} 
(C) Revista SCRIBES & Viçosa, $M G$ & v. 1 & n. 1 & Julho/2020 & ISSN 2675-4401
\end{tabular}


sindical, buscou-se conhecer como o órgão se posiciona em relação à temática estudada. Inicialmente, procurou-se conhecer de qual maneira o Sindicato toma ciência dos casos de assédio moral ocorrentes com os profissionais de Secretariado Executivo. A entrevistada afirmou que esses casos chegam diretamente a ela através de relatos dos próprios profissionais por contato telefônico, na maioria das vezes. Em poucas situações esses casos chegam por e-mail.

Em seguida, foram questionadas quais providências o órgão toma mediante essas situações. A entrevistada afirmou que o conselho da instituição procura avaliar as possibilidades para resolver o caso, uma vez que os atos punitivos para a ação do assédio moral seriam prerrogativas de um Conselho Federal e não do Sindicato. A entrevistada afirmou que, dentre todas as situações, as que mais impactam são as ponderações indevidas causadas pelo executivo superior diante de terceiros, o que ocasiona uma sensação de inferioridade, incapacidade, tornando o trabalho diário improdutivo. Novamente, comprova-se que o superior imediato do profissional de secretariado executivo é o mais comum como praticante do assédio.

Acerca da frequência dos casos de assédio moral que o sindicato recebe, a presidente afirmou que estes são muito frequentes e que o ideal seria que não existissem. Tal fato, mais uma vez, retoma os resultados da pesquisa de campo via questionário junto a profissionais de secretariado executivo de todo o Brasil, que indicaram que essa prática é comum junto a esses profissionais. Por fim, no que tange à posição do sindicato com relação a esse cenário, a entrevistada afirmou que este assume o posicionamento de ouvir e orientar os profissionais.

Assim, percebe-se que, de forma geral, o posicionamento da presidente está muito associado ao da entrevistada anterior no que se referem aos causadores, consequências e frequência do assédio moral. Esse cenário negativo pode ser minimizado a partir da conscientização de todos os profissionais de uma organização, que devem reconhecer e, acima de tudo, respeitar a atuação dos profissionais de secretariado, que, por sua vez, devem posicionar-se e denunciar esses atos.

Relaciona-se, por fim, as afirmações da entrevista com o que foi destacado no referencial por Freitas (2002), Alkimin (2008) e Hirigoyen (2008) sobre a importância das organizações e profissionais em geral no combate ao assédio moral e na propagação da manutenção do bom 
clima organizacional, propício a relações de trabalho saudáveis.

\section{Considerações Finais}

Investigar a temática do assédio moral torna-se fundamental para verificar essa prática junto ao profissional de secretariado executivo e demonstrar como a pesquisa científica pode contribuir de forma a combatê-la e preveni-la. Identificou-se, a partir dos questionários com profissionais de secretariado executivo de todo o Brasil, que a maioria destes tem ciência de 1 a 4 casos de assédio com profissionais dessa área. Essa situação se torna ainda mais alarmante quando $64 \%$ dos respondentes afirmaram sofrer ou ter sofrido assédio enquanto profissionais de secretariado executivo, sendo que, destes, 54\% informaram ter sofrido assédio moral e $10 \%$ assédio sexual. Além disso, foi possível constatar que boa parcela dos profissionais que sofreram assédio moral não tomou nenhuma providência com relação aos fatos por medo de perder o emprego ou por medo do executor do assédio.

Referente ao objetivo específico (a) da pesquisa, foi possível constatar, a partir dos questionários e reforçado pelas entrevistas, que a maioria dos profissionais afirmam que a prática de assédio moral foi realizada por seu superior direto. Em relação às consequências causadas por esse tipo de agressão, tanto na vida pessoal quanto na carreira profissional das vítimas, o que compreende o objetivo específico (b), constatou-se que, entre os danos causados às vítimas, o estresse foi expressivamente mais citado entre os respondentes do questionário e as entrevistadas.

Para finalizar a investigação, compreendendo todos os profissionais que participaram da pesquisa, em relação às medidas que poderiam ser adotadas pelas empresas para o combate ao assédio moral, o mais citado está relacionado ao posicionamento da organização em demonstrar que existem canais de reclamação e que estes estão disponíveis para o recebimento de denúncias, com o propósito de gerar um bom clima organizacional e tomar as providências cabíveis diante da situação. Fazendo relação com esse item, percebe-se que ele pode ser justificado pelo pequeno 
percentual de profissionais que afirmaram ter procurado o setor responsável para registrar uma denúncia após ter sofrido assédio moral.

As entrevistas foram fundamentais para reforçar os resultados encontrados na pesquisa de campo, que, por sua vez, tiveram representatividade de profissionais de todos os estados do Brasil, evidenciando que esse cenário é comum e necessita de maior atenção, conscientização e combate. De maneira geral, acredita-se que a pesquisa tenha alcançado os objetivos propostos, entretanto, é necessário que novas pesquisas sejam empreendidas dentro dessa temática, a fim de combater e prevenir que a prática do assédio moral aconteça junto aos profissionais de secretariado executivo.

\section{Referências}

Alkimin, M. A. (2008). Assédio moral na relação de trabalho. 2 ed. rev. e atual. Curitiba: Juruá. $\begin{array}{lllll}\text { Recuperado em } 27 \text { de } & \text { outubro, }\end{array}$ https://www.jurua.com.br/bv/conteudo.asp?id=23094

Barreto, M. A. A. (2007). Assédio moral no trabalho: da responsabilidade do empregador perguntas e respostas. São Paulo: LTr.

Carvalho, N. G. (2009). Assédio moral na relação de trabalho. São Paulo: Rideel.

Código de Ética da Profissão de Secretariado Executivo. Diário Oficial da União, 7 jun. Recuperado em 18 de novembro, 2016, de http://www.jusbrasil.com.br/diarios/3589665/pg-118-secao-1-diario-oficial-da-uniaodou-de-07-07-1989

Constituição da República Federativa do Brasil. Brasília, DF, Senado. Recuperado em 15 de novembro, 2016, http://www.planalto.gov.br/ccivil_03/Constituicao/Constituicao.htm

Código de Ética do Profissional de Secretariado. (2007). Recuperado em 12 de janeiro, 2016, de www. fenassec.com.br 
Einarsen, S. et al. (2003). The concept of bullying at work. The european tradition. In: Einarsen, S. et al. (Eds.). Bullying and emotional abuse in the workplace: international perspectives in research and practice. London: Taylor and Francis.

Fenassec. (2016a). A origem da profissão de secretária. Recuperado em 18 de novembro, 2016, de http://www.fenassec.com.br/b_osecretariado_historico.html

Fenassec. (2016b). Apresentação. Recuperado em 18 de novembro, 2016, de http:/www.fenassec.com.br/a_fenassec_apresentacao.html

Freitas, M. E. (2002). Assédio moral e assédio sexual. In: WOOD JUNIOR, Thomaz. Gestão Empresarial: o fator humano. São Paulo: Atlas.

Gil, A. C. (2008). Como elaborar projetos de pesquisa. 4. ed. São Paulo: Atlas.

Gonçalves, R. C. (2006). O assédio moral no Ceará: naturalização dos atos injustos no trabalho. Dissertação (mestrado) - Universidade de Fortaleza.

Heloani, R. (2004). Assédio moral: Um ensaio sobre a exproproação da dignidade no trabalho. ERA - Revista de Administração de Empresas. São Paulo, vol.3, n.1, art. 10, p. 2-8, Jan./Jun.

Hirigoyen, M. F. (2008). Assédio moral: a violência perversa no cotidiano. $10^{\circ}$ ed. Rio de Janeiro: Bertand Brasil.

Leal, F. (2014). Competências secretariais requeridas pela Universidade Federal de Santa Catarina. Dissertação (mestrado). Florianópolis: Universidade Federal de Santa Catarina.

Lei n. 2.949, 19 de abril de 2002, determina sanções à prática de assédio moral. Brasília. $\begin{array}{lllll}\text { Recuperado em } 15 \quad \text { de } & \text { novembro, 2016, }\end{array}$ http://www.tc.df.gov.br/SINJ/Arquivo.ashx?id_norma_consolidado=50905

Lei $n$. 7.377, de 30 de setembro de 1985, dispõe sobre o Exercício da Profissão de Secretário, e dá outras Providências. Recuperado em 15 de novembro, 2016, de http://www.planalto.gov.br/ccivil_03/leis/17377consol.htm

Lei $n$. 8.112, de 11 de dezembro de 1990, dispõe sobre o regime jurídico dos servidores públicos civis da União, das autarquias e das fundações públicas federais. Recuperado em 15 de novembro, 2016, de https://www.planalto.gov.br/ccivil_03/leis/L8112cons.htm

Lei n. 15.036, de 18 de novembro de 2011, dispõe sobre o assédio moral no âmbito da administração pública estadual e seu enfrentamento, visando a sua prevenção, 
repreensão e promoção da dignidade do agente público no ambiente de trabalho, e dá outras providências. Fortaleza: 2011. Recuperado em 15 de novembro, 2016, de http://www.al.ce.gov.br/legislativo/legislacao5/leis2011/15036.htm

Maciel, E. (2015). Secretaria do Planejamento e Gestão. Assédio moral no trabalho: estratégias de prevenção e combate na administração pública do Ceará. Fortaleza. Recuperado em 15 de novembro, 2016, de file://C:/Users/R/Desktop/Ass\%C3\%A9dio\%20Moral\%20\%20Rede\%20de\%20Planejamento.pdf

Martiningo, A., Filho \& Siqueira, M. V. S. (2008). Assédio moral e gestão de pessoas: Uma análise do assédio moral nas Organizações e o papel da área de Gestão de pessoas. RAM - REVISTA DE ADMINISTRAÇÃO MACKENZIE, Volume 9, n. 5, p. 11-34. Recuperado em 30 de maio, 2017, de http://www.scielo.br/pdf/ram/v9n5/a02v9n5

Melo, M. M. B. (2016). Empregabilidade profissional: o secretariado executivo em foco na amazônia setentrional. Revista de Gestão e Secretariado -GeSec, São Paulo, v. 7, n. 3, pp. 66-95, set./dez.

Muller, R. \& Sanches, F. C. (2014). Pesquisa acadêmica em secretariado executivo: um estudo de caso na revista expectativa. Revista Expectativa. Volume XIII - n 13. pp. 09-28.

Orlandi, E. P. (2001). Leitura e discurso. São Paulo: Cortez.

Paes, R. V. O. et al. (2015). Novas formas de atuação do profissional de Secretariado Executivo. Revista de Gestão e Secretariado - GeSec, São Paulo, v. 6, n. 1, p 99-125, jan./abr. Recuperado em 29 de maio, 2017, de https://www.revistagesec.org.br/secretariado/article/view/318/pdf_64

Paim, A. S. \& Pereira, M. El. (2010). Estereótipos, boa aparência e a secretária executiva. Revista do Secretariado Executivo, Passo Fundo, pp. 29-40, n. 6. Recuperado em 19 de julho, 2017, de http://seer.upf.br/index.php/ser/article/view/2098/1546

Projeto de Lei n. 4.742-A, introduz art. 146-A no Código Penal Brasileiro - Decreto-lei $\mathrm{n}^{\circ} 2.848$, de 07 de dezembro de 1940, dispondo sobre o crime de assédio moral no trabalho. Brasília. Recuperado em 27 de outubro, 2016, de http://www.camara.gov.br/proposicoesWeb/prop_mostrarintegra;jsessionid=50F68D5E 6F66E303579F9ACC340281AE.proposicoesWeb1?codteor $=1442937 \&$ filename=Avuls o+-PL+4742/2001

Rodrigues, M. C. \& Oliveira, L. N. (2012). A percepção do código de ética para os profissionais de secretariado executivo: um estudo de caso com os estagiários e graduados da Universidade Federal de Viçosa (UFV). Revista do Secretariado Executivo, Passo 
Fundo, pp. 89-102, n. 8. Recuperado em 17 de novembro, 2016, de http://seer.upf.br/index.php/ser/article/view/3038

Rodrigues, Antônia Aline; Rosa, Jaqueline Silva; Ferko, Geórgia Patricia Silva \& Santiago, Cibelle da Silva; Santos, Maria Luzitana C. (2009). Um estudo sobre o assédio moral no trabalho para o profissional de Secretariado. Secretariado Executivo em Revista, v. 5, Passo Fundo. Recuperado em 25 de novembro, 2016, de http://seer.upf.br/index.php/ser/article/view/1779/1659

Santos, M. E. \& Moretto, C. F. (2011). O mercado de trabalho do secretário executivo no contexto da dinâmica produtiva e do emprego recentes no Brasil. Revista do Secretariado Executivo. Passo Fundo, 7, pp. 21-35.

Schraiber, L. B. (1995). Pesquisa qualitativa em saúde: reflexões metodológicas do relato oral e produção de narrativas em estudo sobre a profissão médica. Rev. Saúde Pública, 29(1): pp. 63-74.

Terra, E. F., Uchimura, J., \& Scopinho, R. A. (2012). A exposição de estereótipos do secretário executivo veiculados pela mídia. Revista Linguagem Acadêmica, Batatais, v. 2, n. 1, pp. 73-91, jan./jun.

Whitaker, M. C. \& Cavalcanti, T. N. (2010). Ética e sigilo na empresa e os profissionais de Secretariado. Revista de Gestão e Secretariado, São Paulo, v. 1, n. 1, pp. 25-45, jan./jun. Recuperado em 25 de novembro, 2016, de https://docs.google.com/viewerng/viewer?url=https://www.revistagesec.org.br/secretari ado/article/viewFile/2/71 